\title{
Late-glacial marine invertebrate macrofossils from Point Lepreau, New Brunswick
}

\author{
Randall F. Miller and Jeffrey $\mathrm{H}$. McGovern \\ Steinhammer Palaeontology Laboratory, New Brunswick Museum, \\ 277 Douglas Avenue, Saint John, New Brunswick E2K IE5, Canada
}

Date Received April 14, 1997

Date Accepted July 14, 1997

\begin{abstract}
A late-glacial shell fauna from Point Lepreau, New Brunswick produced a radiocarbon date of 13,500 years B.P. The assemblage contained well-preserved subarctic to boreal molluscs and barnacles typical of late Pleistocene marine deposits from the region. Rare specimens of sea urchin, crab and brittlestar may be the oldest recorded occurrence of these animals in the late-glacial Bay of Fundy. The assemblage fits into a previously defined Zone 3, late-glacial marine invertebrate assemblage in the Bay of Fundy-Gulf of Maine region, characterized as a Diverse Arctic assemblage.

La datation par le radiocarbone a situé à 13500 ans BP une faune invertébrée tardiglaciaire de la pointe Lepreau, ou Nouveau-Brunswick. L'assemblage renferme des mollusques et des bernacles subarctiques à boréaux bien conservés caractéristiques des dépôts marins du Pléistocène tardif de la région. Les spécimens rares d'oursins, de crabes et d'ophiures pourraient constituer les manifestations les plus anciennes de la présence de ces animaux relevées dans la région tardiglaciaire de la baie de Fundy. L'assemblage se situe à l'intérieur de l'assemblage d'invertébrés marins tardiglaciaires de la zone 3 antérieurement défini dans la région de la baie de Fundy et du golfe du Maine, caractérisé en tant qu'assemblage arctique hétérogène.
\end{abstract}

[Traduit par la rédaction]

\section{INTRODUCTION}

Late-glacial marine invertebrate fossils occur in marine sediments that fringe the modern shoreline of New Brunswick. The earliest observations of Quaternary marine invertebrate fossils were made by Abraham Gesner during his geological survey of New Brunswick (Gesner, 1840, 1841) in which he noted shells, including Mya, Pecten and Mytilus, from clays found in the Saint John region. The first comprehensive list of Quaternary marine invertebrate fossils was complied by C.F. Hartt and published in Loring Bailey's Observations on the Geology of Southern New Brunswick (Hartt, 1865). One of the best exposures occurs at Sheldon Point in west Saint John (Rampton et al., 1984) where mollusc shell dates range from $13,900 \pm 620$ (GSC-3354) to $11,620 \pm 250$ years B.P. (BGS-1223) (Walton et al., 1961; Gadd, 1973; Blake, 1983; Rampton et al., 1984; Nicks, 1991). A rich invertebrate assemblage, recently discovered at the Point Lepreau Generating Station (Fig. 1), includes common mollusc species found in New Brunswick (Nicks, 1991; Seaman et al., 1993), but also specimens of sea urchin, crab and brittlestar, that may be the oldest recorded late-glacial occurrence of these animals in the Bay of Fundy. An excellent overview of marine molluscs in glaciated North America during the last 18,000 years by Dyke et al. (1996) provides a framework for characterizing the Point Lepreau assemblage.

\section{LOCATION AND STRATIGRAPHY}

Quaternary marine clays near Saint John form thick red deposits interbedded with sandy layers (Gadd, 1973; Rampton et al., 1984). Molluscs, barnacles, ostracodes, foraminifera, and, less commonly, crabs, sea urchins, and brittlestars are found in red marine clay. In May, 1995, excavations at the Point Lepreau Generating Station $\left(45^{\circ} 04^{\prime} 10^{\prime \prime} \mathrm{N}, 66^{\circ} 27^{\prime} 30^{\prime \prime} \mathrm{W}\right)$ exposed a fossiliferous band 20 to $100 \mathrm{~cm}$ thick, within marine clay, about $24 \mathrm{~m}$ above mean sea level. Collections made by $M$. Fairweather and M. Mersereau of the Point Lepreau Generating Station were turned over to the New Brunswick Museum for identification. No opportunity was available to examine the site before it was covered. Access to the site may become possible if construction resumes in a few years. Description of the site suggests samples were recovered from a narrow embayment enclosed by bedrock on three sides (M. Mersereau, personal communication, 1997). The samples contained a rich assemblage of invertebrate fossils. Sample blocks preserved intact suggest a death assemblage, although articulated valves of Hiatella arctica and Portlandia arctica may indicate relatively short transport. About 25 to $30 \mathrm{~kg}$ of fossiliferous sediment was soaked in water and washed through a 40 mesh sieve to recover hundreds of macrofossils (Table 1). Some untreated samples were retained. All specimens are in the New Brunswick Museum palaeontology collection. A $40 \mathrm{~g}$ sample of the pelecypod Hiatella arctica 


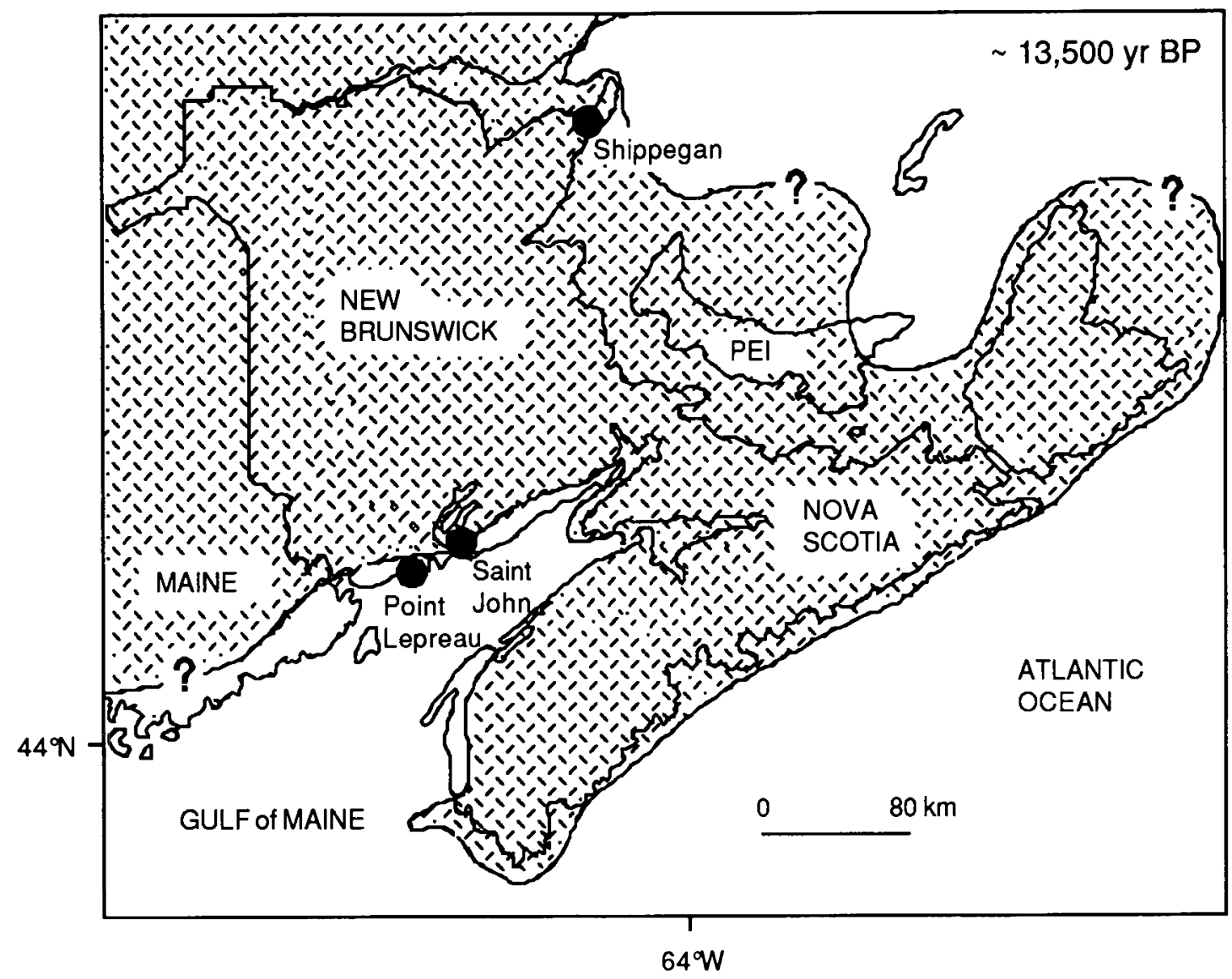

Fig. 1. Location of late-glacial marine invertebrates from Point Lepreau, Saint John and Shippegan, New Brunswick. Approximate glacial ice cover, shown at about 13,500 years B.P., compiled from Rampton et al. (1984), Stea et al. (1992) and Dyke et al. (1996).

produced a corrected radiocarbon date of $13,500 \pm 100$ years B.P. (WAT-2980). To make this comparable to Geological Survey of Canada radiocarbon data, such as those used in Dyke et al. (1996), a second marine reservoir correction of -400 years should be applied.

\section{Results}

The assemblage of marine invertebrate fossils recovered from Point Lepreau (Table 1) is dominated by molluscs and contains species commonly reported from late-glacial marine assemblages in New Brunswick (Nicks, 1991; Seaman et al., 1993). The pelecypod Hiatella arctica, some with valves still articulated, comprised almost 80 percent of the mollusc assemblage, with the clams Portlandia arctica and Macoma calcarea being fairly common and comprising about $\mathbf{1 6}$ percent of the molluscs. A specimen of snail, Retusa obtusa, is rarely encountered in late-glacial deposits in New Brunswick. The only other regional late-glacial occurrences of $R$. obtusa found in the literature are from Sheldon Point, Saint John (Welsted, 1976; Nicks, 1991) and Champlain Sea deposits near Rivière des Chutes, Québec (Wagner, 1970).

The barnacle Balanus crenatus was also common, although minimum numbers are difficult to assess. Foraminifera, ostracode, snail, brittlestar, sea urchin and crab remains were rare, but their occurrence indicates a relatively diverse assemblage. Although the sea urchin Strongylocentrotus droebachiensis and the brittlestar Ophiura sarsi have been described from deposits along the Bay of Fundy (Miller and McAlpine, 1991), they have never been recorded from a dated assemblage. Their appearance at Point Lepreau represents the earliest late-glacial occurrence of these echinoderms in the Bay of Fundy. Likewise, the occurrence of a 'spider' crab, likely Hyas araneus or $H$. coarctatus, is the earliest record from the Family Majidae in the Bay of Fundy.

The modern ecology and distribution of the identified species indicates a predominately subarctic to boreal assemblage (Dyke et al., 1996). Some species exhibit wide ranges in distribution from the Arctic to the Caribbean. Southern populations, south of the Gulf of Maine-Bay of Fundy, usually occur in deeper water. The ecology and western Atlantic distribution of species is summarized below.

Buccinum (tenuis) scalariforme, is an arctic to boreal snail found south to Maine (Abbott, 1974; Dyke et al., 1996). It is commonly found in waters from 15 to $180 \mathrm{~m}$ deep. Members of this genus of whelk are carnivorous.

Retusa obtusa, the arctic barrel-bubble, is a small snail (3 $\mathrm{mm}$ long) that occurs from the Arctic seas to waters off North Carolina. It lives on muddy or sandy bottoms of colder waters from low tide level to $500 \mathrm{~m}$ (Bousfield, 1960; Abbott, 1974). 
Table 1. List of late-glacial marine invertebrate macrofossils from Point Lepreau, New Brunswick.

Taxa

Relative abundance

Modern Distribution

(minimum \# individuals)

\author{
MOLLUSCA \\ Gastropoda \\ Buccinum scalariforme Möller \\ cf. Retusa obtusa (Montagu) \\ Pelecypoda \\ Hiatella arctica (Linné) \\ Macoma calcarea (Gmelin) \\ Mya truncata Linné \\ Nucula tenuis (Montagu) \\ Portlandia arctica (Gray)
}

\section{ARTHROPODA \\ Cirripedia}

Balanus crenatus Bruguière

Decapoda

cf. Hyas araneus (Linnaeus)

or $H$. coarctatus Leach *

\section{ECHINODERMATA}

Ophiuroidea

cf. Ophiura sarsi Lutken

Echinoidea

Strongylocentrotus droebachiensis Muller

$\begin{array}{ll}\begin{array}{ll}\text { rare (6) } \\ \text { rare (2) }\end{array} & \begin{array}{l}\text { arctic-boreal } \\ \text { arctic-boreal }\end{array} \\ \text { common (466) } & \text { arctic-subarctic } \\ \text { common (47) } & \text { arctic-subarctic } \\ \text { rare (4) } & \text { arctic-subarctic } \\ \text { rare (17) } & \text { subarctic-boreal } \\ \text { common (48) } & \text { arctic }\end{array}$

common $(>>1) \quad$ widespread

rare (5) subarctic-boreal

*Specimens probably belong to the Family Majidae, Subfamily Oregoniinae which includes three species Chionoecetes opilio, Hyas coarctatus and Hyas araneus.

Hiatella arctica is a common cold water clam that occurs from the Arctic to deeper water in the West Indies. It nests in kelp holdfasts and rock crevices from low tide to $180 \mathrm{~m}$ (Gosner, 1979). It is largest, up to about $5 \mathrm{~cm}$ long, in the coldest seas (Rogers, 1936). The maximum valve length recorded from Point Lepreau was $3.8 \mathrm{~cm}$.

Mya truncata is found from the Arctic to Cape Cod. It occurs in the lower intertidal zone in the north. South of the Bay of Fundy it occurs from the subtidal zone to depths of $30 \mathrm{~m}$ (Gosner, 1979).

Nucula tenuis occurs from Labrador south to Maryland. Nut shells are common on muddy bottoms of bays and sounds where they are preyed upon by fish (Gosner, 1979).

Portlandia arctica is an arctic species of clam found in the Arctic Ocean and near Greenland, south to Hamilton Inlet, Labrador. It is found in deeper waters only in the subarctic (Dyke et al., 1996).
Macoma calcarea is a cold water clam that occurs from Greenland to Long Island. It is found from the subtidal to 75 m (Bousfield, 1960).

Balanus crenatus is a widespread barnacle found from the Arctic to New Jersey. It is a common subtidal species found from low tide level to more than $90 \mathrm{~m}$ (Bousfield, 1960).

Hyas araneus and $H$. coarctatus are 'spider' crabs that have a subarctic to boreal distribution in the western Atlantic south to the Gulf of Maine. H. coarctatus is found in Hudson Bay while $H$. araneus occurs in waters off Greenland (Squires, 1990). They are found in waters from depths of 0 to 1,650 $\mathrm{m}$ and 0 to $360 \mathrm{~m}$, respectively, on hard, stony, sandy and soft bottom sediments, although $H$. araneus is more common on soft sediment. These crabs are known to have a varied diet that includes many of the kinds of organisms recovered from the Point Lepreau site. Stomach contents from modern Hyas have included phytobenthos, crustacean fragments (amphipods and ostracodes), small crabs, hermit crabs, 
polychaetes, foraminiferans, brittle stars, bivalves, gastropods, chitons and sea urchins. Chionoecetes opilio, the third member of the Subfamily Oregoniinae, has a similar distribution and habit to species of Hyas (Williams, 1984; Squires, 1990).

Strongylocentrotus droebachiensis is a widespread, euryhaline echinoid extending to the high Arctic. It is a common subtidal benthic animal found from intertidal pools to depths of almost 1,000 $\mathrm{m}$ (Miller and Bishop, 1973). It feeds on a variety of non-calcareous algae such as Laminaria, and is preyed upon by lobsters, crabs, starfish, birds and fish (Himmelman and Steele, 1971). Laboratory studies have determined that $10^{\circ} \mathrm{C}$ is the upper limit for larval growth and that its distribution correlates well with this experimental value. It is found in seas where temperature during the spring rarely exceed 6 to $8^{\circ} \mathrm{C}$.

Ophiura sarsi can be found on mud bottoms from the intertidal zone to depths of about $3,000 \mathrm{~m}$. It is commonly reported from depths of 70 to $140 \mathrm{~m}$. In the North Atlantic it occurs from Greenland to as far south as Georgia. Thorson (1971) described typical $O$. sarsi communities in waters near Denmark. In the sublittoral zone it was associated with bivalves, amphipods, acorn worms, sea mice and bristle worms.

\section{Discussion}

Beginning about 14,000 years ago glacier ice retreated from New Brunswick leaving most of the province ice-free by 12,000 years B.P. Proposed ice margins from 14,000 to 13,000 vary widely between authors (Rampton et al., 1984; Stea et al., 1992; Dyke et al., 1996), but some place the glacier front near the present New Brunswick, Bay of Fundy coast 13,500 to 13,000 years ago (Fig. 1). Most marine sediments fringing the coastline were likely deposited before 12,300 years B.P. (Rampton et al., 1984). The oldest radiocarbon date establishing the opening of the Bay of Fundy at 14,400 \pm 530 years B.P. (GSC-2573) comes from Hiatella arctica specimens found near Mispec, Saint John (Lowden and Blake, 1979). Nicks (1991) reported a date of $13,900 \pm 620$ years B.P. (GSC-3354) on Hiatella arctica shells from Sheldon Point in Saint John. Hiatella arctica shells from Point Lepreau described here were dated as 13,500 years B.P., one of the oldest dates for the Bay of Fundy.

The marine fossil assemblage described from Sheldon Point, not far from Point Lepreau (Fig. 1), is the best-documented late-glacial shell site in New Brunswick. Gadd (1973) suggested a nearshore intertidal environment for the Sheldon Point deposit. Nicks (1991) described the deposit as a glaciomarine end moraine, a time transgressive sequence $(14,000$ to 10,000 years B.P.) from a tidewater glacier to subaerial exposure. Molluscs include a number of 'cold' water species like Hiatella arctica, Macoma calcarea, and Portlandia arctica (Gadd, 1973). Most of the marine mollusc species can be described as subarctic to boreal species (Gosner, 1979). Gadd (1973) noted the lack of warmer water species such as oysters, scallops and sea urchins in the fauna. In the same paper, results presented from ostracode analysis suggested very cold, shallow water.

Eight 'mollusc zones' were recognized by Nicks (1991) for the late glacial deposits of southern New Brunswick and Maine. Zone $2(14,000$ - 13,500 years B.P.) was characterized by Hiatella arctica and Portlandia arctica. Zones 3 $(13,500-12,900$ years B.P.) and $4(12,900-12,500$ years B.P.) were comprised of a more diverse fauna suggesting an amelioration in climatic conditions and possibly a stratification of the water column to produce an upper less saline horizon with salinity as low as $5 \%$. Zone 3 included both $H$. arctica and $P$. arctica, plus Clinocardium ciliatum, Macoma balthica, M. calcarea, Mya truncata, Retusa obtusa, the gastropod Neptunea despecta tornata and barnacles identified as Balanus sp. Zone 4 lacked the species $H$. arctica and $M$. truncata, but included Mya arenaria, Mytilus edulis, Nuclula expansa, Serripes groenlandicus and the gastropod Buccinum tenue. Zone 5 (12,500 - 12,100 years B.P.) contained molluscs that suggest still warmer conditions and a lack of year round sea-ice cover. Although the assemblage at Point Lepreau straddles the time frames of Zones 2 to 3, the varied fauna suggests it is equivalent to Zone 3 . The Point Lepreau assemblage also includes species described in Zone 4, plus crab and sea urchin fossils not recorded by Nicks (1991).

Dyke et al. (1996) described a subarctic molluscan faunistic zone in the Gulf of Maine-Bay of Fundy region from 14,000 to 13,000 years B.P. They believed that during this interval the boreal zone expanded northward, possibly due to decreased meltwater flux through the Gulf of Maine by 13,000 years B.P., but that the more ice-proximal Bay of Fundy retained an arctic aspect. Interpretation of the Point Lepreau assemblage is consistent with this model. Molluscs from Point Lepreau are arctic, arctic-subarctic and arctic-boreal in distribution. Arthropods and echinoderms from this site have widespread to arctic-subarctic distributions (Table 1). The assemblage from Point Lepreau is similar to the Diverse Arctic assemblage described by Dyke et al. (1996), dominated by Hiatella arctica and Mya truncata, but including, among other species, Macoma calcarea and Portlandia arctica.

Bousfield and Thomas (1975) speculated on late-glacial and postglacial changes in near-surface ocean temperatures based on the distribution of modern littoral marine invertebrates in the Maritimes. Their data demonstrated that between 13,000 and 12,000 years B.P., as ice retreated from most of New Brunswick, water temperatures adjusted to changing currents and sea levels. During this time the Strait of Belle Isle opened to allow cold subarctic $\left(<12^{\circ} \mathrm{C}\right.$ summer $)$ waters to penetrate along the St. Lawrence River valley and into the Champlain Sea. They estimated that temperatures in the Bay of Fundy by about 12,500 years B.P. were less than $12^{\circ} \mathrm{C}$ in summer.

Invertebrate fossils are reasonably common in late-glacial marine sediments along the New Brunswick coastline (Rampton et al., 1984). Pelecypods dominate most assemblages and barnacles are often common. Although few brittlestar and sea urchin remains are known (Miller and McAlpine, 1991), 
both were noted from Saint John as early as 1865 (Hartt, 1865). The Sheldon Point-Duck Cove-Sand Cove locality in west Saint John has been the principal source of brittlestars. Specimens in the New Brunswick Museum record crab occurrences at Sheldon Point, Duck Cove, and Red Head in Saint John, although some may be modern contaminants. The only late-glacial occurrence of crab (Cancer irroratus) and sea urchin (Strongylocentrotus droebachiensis) fossils in New Brunswick that have been dated, other than at Point Lepreau, are from a deposit near Shippegan (Thomas et al., 1973). In addition to sea urchins and crabs, this site contained a diverse assemblage of clams and snails. Radiocarbon dating of Mytilus edulis shells produced a date of 12,600 \pm 400 years B.P., making the assemblage time equivalent to Zone 4 (Nicks, 1991). At 13,000 years B.P., Dyke et al. (1996) show the Bay of Chaleur-Gulf of St. Lawrence region part of the same subarctic faunistic zone as the Bay of Fundy. By 12,000 years B.P., when the Bay of Fundy was well within the boreal faunistic zone, the Shippegan site was still near the subarctic-boreal boundary. It would be reasonable to suspect a more diverse fauna to appear earlier in the Gulf of Maine-Bay of Fundy region. Cancer irroratus has a modern distribution described as boreal, extending from just south of the Gulf of Maine to the Strait of Belle Isle. Species of Hyas coarctatus, Hyas araneus and Chionoecetes opilio are considered subarctic-boreal and are found from the Gulf of Maine north to waters off Greenland or in Hudson Bay. Based on their modern ecology and distribution one might expect these would be among the first species of crab to populate the Bay of Fundy following deglaciation.

\section{ACKNOWLedgements}

Thanks are extended to the staff of N.B. Power Lepreau Generating Station for their help. M. Fairweather and M. Mersereau recognized the importance of the material and collected the samples during the construction work. K. Duguay arranged for financial support of radiocarbon dating through N.B. Power Lepreau Generating Station. A.S. Dyke and S.K. Donovan provided helpful reviews of the manuscript.

Aвbotr, R.T. 1974. American Seashells, 2nd edition. Van Nostrand Reinhold, New York, 663 p.

Blake, W., JR. 1983. Geological Survey of Canada radiocarbon dates XXIII. Geological Survey of Canada, Paper 83-7, 34 p.

Bousfield, E.L. 1960. Canadian Atlantic Sea Shells. National Museum of Canada, Ottawa, 72 p.

Bousfield, E.L. and Thomas, M.L.H. 1975. Postglacial changes in distribution of littoral marine invertebrates in the Canadian Atlantic Region. Proceedings of the Nova Scotia Institute of Science, 27, Supplement 3, pp. 47-60.

Dyke, A.S., Dale, J.E., and McNeely, R.N. 1996. Marine molluscs as indicators of environmental change in glaciated North America and Greenland during the last 18,000 years. Géographie physique et Quaternaire, 50, pp. 125-184.

GADD, N.R. 1973. Quaternary geology of southwest New Brunswick with particular reference to Fredericton area. Geological Survey of Canada, Paper 71-34, $31 \mathrm{p}$.
Gesner, A. 1840. Second Report on the Geological Survey of the Province of New Brunswick. Henry Chubb, Saint John, 76 p.

-... 1841. Third Report on the Geological Survey of the Province of New Brunswick. Henry Chubb, Saint John, 88 p.

Gosner, K.L. 1979. A Field Guide to the Atlantic Seashore. The Peterson Field Guide Series. Houghton Mifflin, Boston, 329 p.

HARTt, C.F. 1865. List of New Brunswick fossils. In Observations on the Geology of Southern New Brunswick, Appendix B. Edited by L.W. Bailey. G.E. Fenety, Fredericton, pp. 143-147.

Himmelman, J.H. and Steele, D.H. 1971. Foods and predators of the green sea urchin Strongylocentrotus droebachiensis in Newfoundland waters. Marine Biology, 9, pp. 315-322.

LowDEN, J.A. and BlAKE, W., JR. 1979. Geological Survey of Canada radiocarbon dates XIX. Geological Survey of Canada, Paper 79-7, $58 \mathrm{p}$.

Miller, R.F. and McAlpine, D.F. 1991. A review of echinoderms from Pleistocene marine deposits near Saint John, New Brunswick. Atlantic Geology, 27, pp. 111-117.

Miller, R.J. and Bishop, C.A. 1973. A Sea Urchin Fishery for Eastern Canada. Fisheries and Marine Service, Biological Station, St. John's, Newfoundland, Circular 19.

Nicks, L.P. 1991. The study of the glacial stratigraphy and sedimentation of the Sheldon Point Moraine, Saint John, New Brunswick. New Brunswick Department of Natural Resources and Energy, Mineral Resources, Open File Report 91-12, $171 \mathrm{p}$.

Rampton, V.N., Gauthier, R.C., Thibault, J., and Seaman, A.A. 1984. Quaternary Geology of New Brunswick. Geological Survey of Canada, Memoir 416, $77 \mathrm{p}$.

Rogers, J.E. 1936. The Shell Book. Charles T. Branford, Boston, $503 \mathrm{p}$.

Seaman, A.A., Broster, B.E, Cwynar, L., Lamothe, M., Miller, R.F., and Thibault, J.J. 1993. Field Guide to the Quaternary Geology of Southwestern New Brunswick. New Brunswick Department of Natural Resources and Energy, Mineral Resources, Open File Report 93-1, 102 p.

Squires, H.J. 1990. Decapod Crustacea of the Atlantic coast of Canada. Canadian Bulletin of Fisheries and Aquatic Sciences, $221,532 \mathrm{p}$.

Stea, R.R., Conley, H., and Brown, Y. 1992. Surficial Geology of the province of Nova Scotia. Nova Scotia Department of Natural Resources, Map 92-3, Scale 1: 500000.

Thomas, L.H., Grant, D.R., and DE Grace, M. 1973. A late Pleistocene marine shell deposit at Shippegan, New Brunswick. Canadian Journal of Earth Sciences, 10, pp. 1329-1332.

Thorson, G. 1971. Life in the Sea. McGraw-Hill, Toronto, 256 p.

Wagner, F.J.E. 1970. Faunas of the Pleistocene Champlain Sea. Geological Survey of Canada Bulletin, 181, $104 \mathrm{p}$.

Walton, A., Trautman, M.A., and Friend, J.P. 1961. Isotopes Inc., radiocarbon measurements I. American Journal of Science, Radiocarbon Supplement, 3, pp. 47-59.

Welsted, J. 1976. Post-glacial emergence of the Fundy Coast: An analysis of the evidence. Canadian Geographer, 20, pp. 367-383.

Williams, A.B. 1984. Shrimps, lobsters, and crabs of the Atlantic coast of the eastern United States, Maine to Florida. Smithsonian Institution Press, Washington, $550 \mathrm{p}$.

Editorial Responsibility : R.K. Pickerill 